\title{
Fostering Private Equity Using a Law-First Approach: Lessons from South Korea
}

\author{
Sung Eun (Summer) KIM* \\ University of California, Irvine, USA \\ skim@law.uci.edu
}

\begin{abstract}
In 2004, South Korean lawmakers introduced sweeping legislation to regulate Korean private equity funds. I describe this Korean regulatory initiative as a 'law-first' approach to financial regulation: the laws first clearly outline the terms of an ideal private equity structure, and private equity funds and their managers are required to comply with such terms to gain entry into the Korean private equity market. Elsewhere, private equity funds are referred to as shadow banks, with the descriptor 'shadow' referring to the funds' ability to remain outside of the regulatory purview. Attempts to regulate private equity funds and other shadow banks more extensively have been resisted with claims that such regulation will go either too far and regulate shadow banks out of existence, or not nearly far enough as shadow banks expediently exploit loopholes to navigate around new regulation. This article presents the Korean private equity regulatory regime as a counterexample to the existing discourse by showing that private equity funds can survive, and in some cases thrive, under a law-first regulatory approach.
\end{abstract}

This article examines South Korea's efforts to launch and foster a domestic private equity market using law. What is most surprising about the Korean regulatory initiative is what I term its 'law-first' approach to regulating private equity funds. ${ }^{\mathrm{I}}$ The regulations clearly outline the terms of an ideal private equity fund structure, and then require private equity funds and their managers to comply with such terms as a condition of entry into the Korean private equity market. ${ }^{2}$ Korean regulators not only

\footnotetext{
* $\quad$ BA (Seoul National University), JD (Harvard Law School) and admitted to the New York and California bars (both currently inactive). Assistant Professor of Law and Director, Korea Law Center, University of California, Irvine, School of Law. I wish to thank Afra Afsharipour, Funmi Arewa, Jonathan Glater, Joan Heminway, Hwang Lee, Soonkoo Myoung, Donna Nagy, Jeff Schwartz, and Chris Whytock for their helpful comments and discussions on earlier drafts, and Christina Tsou and Jessica Pierucci of the UC Irvine Law Library for their invaluable research assistance.

I. For a survey of various approaches to financial regulation, see John Armour et al, Principles of Financial Regulation (OUP 2016) 86, 505, 55 I. As between formal versus functional approaches, Korea can be said to take a functional approach to financial regulation, which regulates financial instruments according to their function rather than by the type of institution that is offering such financial instruments. See Ministry of Justice of the Republic of Korea, 'Introduction of the Financial Investment Services and Capital Markets Act' (International Affairs Division, Ministry of Justice, Republic of Korea 2013) 64-67.

2. For a primer, see Hwa-Jin Kim and Alice Z Chen, 'Private Equity in Korea: History, Industry and Policy' in Hwa-Jin Kim (ed), Korean Business Law (Edward Elgar 2012) 199, and Hee Jeu Kang and Hyun Kim,
} 
regulate entry, but they also have the power to force exit, require extensive disclosures, and control the timing and scope of permissible activities of private equity funds and their managers. ${ }^{3}$ In addition, a dedicated private equity team under the Financial Supervisory Service (the 'FSS PEF team') maintains a separate register of private equity funds that is publicly disclosed on its website. ${ }^{4}$

Several commentators have criticized the Korean approach to regulating private equity as heavy handed and imposing distortive barriers to entry. ${ }^{5}$ They suggest moving to the United States' and other jurisdictions' mode of regulating private equity funds, in which markets rather than laws regulate entry, exit, and funds' activities. Indeed, private equity funds have sometimes been referred to as shadow banks, because of their ability to perform bank-like activities while being exempt from bank regulatory oversight. ${ }^{6}$ Private equity funds emerged in the United States (US) in the r93os specifically to fill the gap created by bank regulation that prevented merchant banks from being both a depository bank and an investment bank. ${ }^{7}$ By operating in spaces where traditional banks could not due to regulatory constraints, private equity funds were able to grow to impressive and unprecedented levels. Due to this history and more recent developments, private equity funds have been subjected to lighter touch regulation compared to depository institutions, and any attempts to move the needle toward increased regulation have been met with great resistance. ${ }^{8}$

In this article, I use the example of Korean private equity regulation to show that private equity funds can under certain circumstances survive, and even thrive, under a heavy-handed regulatory approach. First, I show how the early stages of Korean private equity regulation are similar to the early stages of US financial regulation, where the goal was to introduce a new institution into the market. As an example,

'The Present and Future of Private Equity Funds (PEF) in Korea' in Hwa-Jin Kim (ed), Korean Business Law (Edward Elgar 2012) 2 I 8.

3. Jong Hyun Park, Joon B Kim, and Byoung Kwon Park, 'Private Equity in South Korea: Market and Regulatory Overview' (Thomson Reuters Practical Law Country Q\&A 8-52 I-4346, I February 20I 5) $<$ https://uk.practicallaw.thomsonreuters.com/8-52I-4346> accessed 5 February 2018.

4. The Financial Supervisory Service (FSS)'s private equity fund registry is updated on a monthly basis and provides the name of the fund, the name of its executive partner, the date of formation (or registration) and the total committed capital amounts.

5. Jung Mi Kang, 'Sa-mo-tu-ja fund-ui hyeon-hwang-gwa gwa-je' [The Current Status and Future of Private Equity Funds]' (The Bank of Korea Reports \& Research Papers, December 2007) <www. bok.or.kr/down.search?file_path=/attach/kor/537/2008/I I/I 22652887375 I.pdf\&file_name=\%EC\%82\%

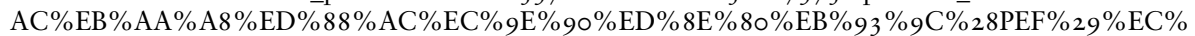
${ }_{9} \mathrm{D} \%{ }_{9} 8+\% \mathrm{ED} \% 98 \% 84 \% \mathrm{ED} \%{ }_{99} \% \mathrm{A9} \% \mathrm{EA} \% \mathrm{~B} 3 \% \mathrm{BC}+\% \mathrm{EA} \% \mathrm{~B} 3 \% \mathrm{BC} \% \mathrm{EC} \% \mathrm{Ao} \%{ }_{9} \mathrm{C} . \mathrm{pdf}>$ accessed 5 February 2018 .

6. The term 'shadow bank' was coined by Paul McCulley in his remarks at the Federal Reserve Bank of Kansas City's Economic Symposium in September 2007, see Paul A McCulley, 'Teton Reflections' (PIMCO Global Central Bank Focus, 5 September 2007) <www.pimco.com/en-us/insights/economicand-market-commentary/global-central-bank-focus/teton-reflections $>$ accessed 20 February 20I 8 . See also Steven L Schwarcz, 'Regulating Shadow Banking' (2OI I-20I2) 3 I Review of Banking \& Financial Law 6I9, 623 (explaining shadow banking and their less regulated status); Imad A Moosa, 'The Regulation of Shadow Banking' (20I7) I 8 Journal of Banking Regulation 6I (arguing that shadow banks should be regulated like traditional banks).

7. John Steele Gordon, An Empire of Wealth: The Epic History of American Economic Power (Harper Perennial 2005).

8. Gretchen Morgenson, 'Private Equity Funds Balk at Disclosure, and Public Risk Grows' The New York Times (New York, I July 2016). 
I note the striking similarities of the early stages of private equity regulation in Korea to the US' business development company (BDC) regulatory regime where the goal was to create a new vehicle to stimulate public investment in private equities. I use this comparative case study to advance my claim that the phases of regulation, rather than the specific features of the product being regulated, may at times be the most important determinant of regulatory strategy, particularly during the introductory phases.

In addition to the theoretical argument, I also present market data to show that the chilling effect of the law-first approach that was feared by critics did not materialize. In 20I0, Korean private equity funds had 20.3 trillion Korean Won (KRW) (20 billion United States Dollar (USD) equivalent) of funds under management, which represented a 200 per cent growth in a less than two-year period (compared to I0.5 trillion KRW in 2008). 9 This is particularly impressive when contrasted with the downward global trend in private equity where private equity fundraising had continuously declined, reverting to 2004 levels in 2010. ${ }^{\text {IO }}$ In addition to these quantitative evaluations of the Korean regulatory approach, I credit Korea's law-first approach for mandating by law the terms that would otherwise have been enjoyed by only a few investors in the absence of regulation. I highlight the important role of financial and regulatory agents in achieving this outcome.

Section I of this article describes the legislative background, regulatory principles, and the market and political conditions that facilitated the law-first approach to regulating private equity in Korea. Section II contrasts the Korean approach with the US and other jurisdictions' regulatory treatment of private equity funds. This regulatory divergence between Korea and the rest of the world has raised concerns that the Korean private equity market would be stunted as a result. Section III introduces the concept of phase-based regulation to guide the selection of the correct comparative framework. Using this framework, I compare Korean private equity regulation to another example of first phase regulation in the US to demonstrate the similarities between the US and Korean approaches. Section IV presents data to show that the chilling effect of regulation feared by critics was largely overstated. In fact, Korean private equity markets have advanced to a level that makes them comparable to the private equity markets of other jurisdictions. Notably, Korea's law-first approach has mandated by law a bargain for all investors of private equity funds that could only have been achieved by a privileged few in the absence of regulation. Section $\mathrm{V}$ describes the role of financial and regulatory agents, and the disciplining role of the law-first approach on such agents in achieving these results. Section VI concludes.

\section{KOREAN PRIVATE EQUITY REGULATION}

\section{A. Background}

Private equity funds invest in the equity of companies that are not publicly-listed. Using this non-traditional investment strategy, some private equity funds have been able to

9. Na Jeong-ju, 'Indigenous Private Equity Funds Flourish' The Korea Times (Seoul, I 5 October 2013).

Io. Bain \& Company, 'Global Private Equity Report' (Bain \& Company 20II), <www.bain.com/Images/ 2OI I-O2-24\% 20REPORT\% 20Global\% 20Private \% 20Equity \% 2oreport \% 2020 I I \% 20- \% 20 MEDIA. pdf $>$ accessed 2I January 20 I 8. 
turn around struggling companies and in turn deliver spectacular returns to their investors. Private equity has been regarded as one of the largest, fastest-growing, and high-yielding asset classes in finance, and this growth has largely been attributed to the ability of private equity to operate in the shadows of law and regulation.

The first appearance of foreign private equity funds in the Korean takeover market was Hambrecht \& Quist (H\&Q) Asia Pacific and Lombard Partners' I 998 acquisition of Good Morning Securities, a Korean financial services company. ${ }^{\text {II }}$ The eventual sale of Good Morning Securities to Shinhan Financial Group resulted in these private equity funds realizing proceeds of 200 million USD on a 30 million USD initial investment. While this transaction is typical for private equity, the magnitude of gains, together with the foreign private equity funds' repatriation of the profits, ${ }^{\mathrm{I} 2}$ led to these private equity funds being caricatured as vultures by the Korean media. ${ }^{\text {I3 }}$

Around the same time, Korea and other Asian economies were hard hit by a financial crisis (the Asian Financial Crisis) of unprecedented dimension. ${ }^{\mathrm{I}}{ }^{\text {In }}$ connection with an emergency bail-out package from the International Monetary Fund (IMF), the Korean government reluctantly agreed to various corporate and financial structural reforms. ${ }^{15}$ In particular, Korea was required to raise its ceiling on aggregate foreign ownership in Korean equities from 26 per cent to 55 per cent, and foreign private equity firms were quick to capitalize on these capital market liberalization measures. ${ }^{16}$

During the five-year period between I 998 and 2003, foreign private equity is estimated to have invested more than 6.6 billion USD in Korean firms. ${ }^{17}$ This influx raised concerns that excessive reliance on foreign private equity could create a funding gap for Korean firms if such capital were to - consistent with the private equity model of ownership abruptly and simultaneously exit from their investments in these firms. ${ }^{18}$

\footnotetext{
II. Alex J Stockham, 'H\&Q Asia Pacific Says Good-Bye to Good Morning in S. Korean Exit' (PrivateEquityCentral.Net 9 April 2002) <www.hqap.com/PDF/news/H\&Q\% 20Asia\% $\%$ 2oPacific\% 20Says \% 20Good-Bye\% 20to\% 20Good\% 20Morning\% 20in\% 20S.\% 20Korean\% 20Exit.pdf> accessed 2I January 2018.

I2. Justin Robertson, 'Financial Returnees as New Agents in East Asia: The Case of Korean Private Equity Funds' (2013) I 8 New Political Economy 579, 589.

I3. Yoon Joo Hwang, 'Jag-nyeon gu-jo-chil-cheon-eog "sil-tan" yu-ib M\&A-ui kko-chi doe-da [Dry Powder of 9.7 Trillion Korean Won Flowers M\&A in 20I3]' (E-Today News, 20 May 20I4) <www.etoday.co. $\mathrm{kr} /$ news/section/newsview.php?idxno=917573> accessed I February 2018.

I4. For a detailed discussion of the causes, management, recovery, and prospects of the Asian Financial Crisis, see Ha-Joon Chang, 'The I 997 Korean Crisis: Causes and Consequences' in Edmund Amann and Ha-Joon Chang (eds), Brazil and South Korea: Economic Crisis and Restructuring (Institute of Latin American Studies, University of London 2004) I07.

I 5. Sanja Samirana Pattnayak and Alka Chadha, 'Role of International Monetary Fund, World Bank and Asian Development Bank in Tackling Financial Crises in Asia' in Kallidaikurichi E Seetharam (ed), A Tale of Two Crises: A Multidisciplinary Analysis (Routledge 2013) 73.

I6. Kunio Saito, 'Korea's Economic Adjustments under the IMF-supported Program' (IMF Regional Office for Asia and the Pacific I998) <www.imf.org/external/np/speeches/I998/or 2198a.pdf> accessed I 5 December 2017.

I7. Dong Hyun Sohn, 'Gi-eob gu-jo-jo-jeong-eu-lo ju-mog-pat-neun sa-mo-tu-ja-peon-deu [Corporate Restructurings Shed New Light on Private Equity Funds]' (Shinhan Bank Future Strategy \& Business Development Report 2008) <http://img.shinhan.com/cib/ko/data/FSB_0907_o8.pdf> accessed I February 20I8.
}

I8. Robertson (n I2) 58 I. 
In addition, the Asian Financial Crisis had also revealed the deficiencies of Korean firms, and Korean regulators saw private equity as an appropriate vehicle to relieve some congestion in the capital markets. ${ }^{19}$ It was hoped that private equity could pool and put to immediate use large amounts of capital that were held in reserve by domestic financial institutions at the time. Second, private equity-led buyouts were viewed as a promising avenue to privatize enterprises in which the government had taken controlling stakes. Third, private equity was also seen as a channel to bolster ongoing governmental efforts to vitalize small and mid-size companies. Fourth, private equity was seen as a viable contender to diffuse some of the capital and power that had been concentrated in large Korean conglomerates (chaebols). Lastly, as pension funds grew, there was a demand for larger and longer term investment opportunities to meet the demands of these funds, and it was expected that private equity could fill this gap. ${ }^{20}$

For all of the foregoing reasons, there was a general consensus that Korean-labelled private equity would be beneficial to the domestic economy, not only as a counterweight to the growing presence of foreign investors in the Korean takeover market but also for long-term growth and prosperity for the Korean economy.

However, the then-existing legal and regulatory framework had foreclosed opportunities for private equity firms to raise capital from Korean investors and, as a result, prompted a new regulatory regime and definition of private equity. While the attempt by Korean regulators to introduce a separate set of laws governing private equity funds may seem suppressive at first glance, a closer look at the then-existing securities laws in Korea showed that legal reforms were necessary to facilitate the growth of the private equity market. Expansively drafted laws which formerly treated publicly- and privately-subscribed funds identically had created unintentional barriers to private equity fund formation.

It was against this backdrop that Korean lawmakers drafted new laws to regulate domestic private equity funds and their managers. What is notable is that Korean regulators did much more than remove the barriers to private equity fund formation: they took this opportunity to introduce sweeping legislation to regulate private equity. The result is one of the most expansive private equity regulatory regimes that forms the backbone of what I term a law-first approach to regulation. On 6 December 2004, Korean lawmakers introduced the Indirect Investment Management Business Act to regulate private equity, which as of 4 February 2009 is contained in the Financial Investment Services and Capital Markets Act (FSCMA). ${ }^{2 I}$

\footnotetext{
19. Financial Supervisory Service (FSS), 'Sa-mo-tu-ja-jeon-mun-hoe-sa Sil-mu-an-nae [PEF Handbook]' (FSS 29 December 20I6) Io <www.fss.or.kr/download.bbs?bbsid=I $207388946537 \&$ fidx $=$ I 4830577 $32755>$ accessed I February 2018.

20. ibid Io.

2I. Ja-bon-si-jang-gwa geum-yung-tu-ja-eob-e gwan-han beob-ryul (자본시장과 금융투자업에 관한 법률) [Financial Investment Services and Capital Markets Act] (promulgated by the National Assembly, 3 August 2007, effective 4 February 2009) Act No 8635. The FSCMA was enacted in 2009 to introduce a single consolidated legal framework to govern the financial services industry which encompasses banking, insurance, and securities. For a primer, see Joon Park, 'Consolidation and Reform of Financial Market Regulation in Korea: Financial Investment Services and Capital Markets Act' (20I I) 6 NTU Law Review 9I, I42.
} 


\section{B. Regulatory Pillars}

As explained above, there was broad market and political consensus that Korea would benefit from a domestic private equity market, and that legal reforms were urgently needed to facilitate its launch. The clearly stated goal of these legal reforms was to increase domestic private equity presence in the domestic takeover market, and this goal was guided by four regulatory principles: (I) setting private equity standards that were not inconsistent with global standards; (2) seeking industry feedback to ensure feasibility; (3) clearly defining the regulatory standards for private equity; and (4) minimizing the number of legal amendments needed. ${ }^{22}$

As demonstrated by the first principle, Korean regulators had decided from the outset that private equity regulation would be mindful of global standards. To implement this regulatory pillar, Korean regulators modeled private equity regulation on the organizational structure and contracts used by foreign private equity funds, and relied on the advice of professionals with foreign private equity experience. What is notable about Korea's law-first approach is that these structures and contracts were facilitated using law, rather than by reliance on private ordering. The role of agents in achieving this outcome is discussed in greater detail in Section V.

In accordance with the second principle, the Korean private equity regulatory process was a collaborative effort which brought together practitioners, lawyers, academics, and researchers. This effort sought feedback from industry and civic groups, including foreign fund operators, with the goal of securing industry and public buy-in to the regulatory regime prior to its launch. The regulators attempted to increase public understanding and support of its private equity vision by organizing and participating in debates hosted by interest groups and civic organizations. These efforts by the regulators to prime and influence the market while the regulators had leverage was a major contributor to the successful implementation of the law-first approach.

In line with the third principle, the Korean private equity regulations outline the terms of the desired private equity structure, and participants were required to conform to such terms as a condition to entry into the Korean private equity market. It was this third pillar of the Korean private equity regulatory strategy that was most heavily criticized by commentators for its potential to stunt innovation and growth. I explain later that it was this feature of Korean private equity regulation that made it possible for a broader segment of private equity investors to enjoy protections that would otherwise have been enjoyed by only a select few in the absence of legally mandated baselines.

Consistent with the fourth principle, the Korean private equity regulations took a streamlined and efficient approach. The primary reason for relying on amendments, as opposed to new legislation, was out of procedural efficiency considerations. In addition, the dedicated FSS PEF team is under the oversight of the Financial Services Commission (FSC) of Korea. ${ }^{23}$ Under a consolidated regulatory regime where a single

22. Jung Hoon Park, 'Sa-mo-tu-ja-jeon-mun-hoe-sa (Private Equity Fund) do-ib-bae-gyeong mich gyeonggwa [Private Equity Funds: Implementation and Progress]' (2005) Io BFL 45, 46.

23. The FSC is an administrative organization under the Prime Minister's Office and is responsible for financial policy and supervision. The FSS is an independent public corporation that is responsible for the 
supervisor had the power to approve and disqualify private equity funds and managers, Korean regulators were free from turf wars.

In summary, the Korean private equity regulatory experience can be characterized as one where new regulations were needed to facilitate and foster new markets, and the regulators utilized this opportunity to use law to define and tightly regulate these markets. What may be lost from this law-first approach is variety but what was gained in return is transparency and fairness. A clean regulatory slate meant lawmakers could set a regulatory ideal and then design laws to achieve the ideal. The goal was to maximize productive private equity activity while keeping private equity's known tendencies of moral hazards under control. ${ }^{24}$ Korean regulators looked to successes and failures of private equity markets around the world to determine which elements to modulate and which to avoid. How this tradeoff was resolved, and whether it is compatible with private equity, has been the subject of debate and is discussed in the following Sections II and III.

\section{ASSESSING KOREA'S LAW-FIRST APPROACH}

Setting the proper level and channel for regulating a financial institution or instrument requires consideration of the special concerns that give rise to financial regulation in the first place. Professor Howell Jackson in his I999 essay explains that the most important policy considerations in the field of financial regulation concern the control of risk. ${ }^{25} \mathrm{He}$ describes the two primary justifications for regulation as first, the inability of public investors to negotiate appropriate safeguards on their own behalf, and second, the negative externalities associated with financial losses and institutional failures. ${ }^{26}$

The widely accepted view has been that neither of these justifications for regulation applied to private equity. ${ }^{27}$ In the US, private equity had flourished in the shadows of regulation, and it was generally understood that these shadow entities fell outside of the publicly-funded safety net that was available to traditional financial institutions and therefore did not require the same level of regulatory intensity. ${ }^{28}$ In addition, private equity raised funds from sophisticated investors who by definition could fend

supervision and examination of financial institutions. For an overview of the Korean financial regulatory landscape, see Ministry of Justice (n I) 49-55.

24. Park (n 22) 5 I. For example, to resolve issues around the question of how to regulate special investment vehicles (SIVs), the Korean regulators' response was to set baseline standards which would allow private equity funds to use SIVs but with the caveat that the regulators would promptly close any loopholes which would allow private equity funds to use SIVs to avoid legal restrictions that would otherwise apply. Park notes that setting rules to curb general partners' moral hazard was a special area of concern for policymakers in designing such regulatory responses.

25. Howell E Jackson, 'Regulation in a Multisectored Financial Services Industry: An Exploratory Essay' (I999) 77 Washington University Law Quarterly 319, 32 I.

26. ibid.

27. Phoebus Athanassiou (ed), Research Handbook on Hedge Funds, Private Equity and Alternative Investments (Edward Elgar 2012) I 59.

28. Zoltan Pozsar et al, 'Shadow Banking' (Federal Reserve Bank of New York Staff Report July 20Iо, Revised February 20I2) <www.newyorkfed.org/medialibrary/media/research/staff_reports/sr458.pdf> accessed I February 2018. 
for themselves. ${ }^{29}$ Therefore, regulators were persuaded that the distribution of costs and benefits of private equity were internalized and that regulation should therefore be limited to preventing spillovers from private equity to the rest of the market rather than regulating the activities of the private equity core.

In the absence of regulation, private equity funds were able to grow to impressive and unprecedented levels. Many observers saw the absence of legal and regulatory interference as a necessary condition to such growth, and any effort to regulate were met with arguments that it would kill innovation and prosperity in the private equity market. And for the most part, private equity funds in the US and elsewhere continued to enjoy light touch regulation (compared to banks and investment funds). Korea broke new ground by designing regulations that reach the core of private equity.

In the following parts, I introduce the specific sections of the FSCMA that give Korean regulators the power to supervise, examine, and shape private equity funds and their managers. I provide a chronological introduction of the regulatory levers that apply at formation, during the first six months, and for the remainder of a private equity fund's life.

\section{A. Formation}

Article 269 of the FSCMA places a number of restrictions on private equity funds even before they are formed. ${ }^{30}$ First, a private equity fund shall not have more than forty-nine partners, and only one of which must be a general partner. ${ }^{3 \mathrm{I}}$ Second, contributions by each partner may not exceed ro billion KRW and must be made in cash. ${ }^{32}$ Third, the length of the private equity fund must be determined at the outset and may not exceed 15 years. ${ }^{33}$ Private equity funds that satisfy these and other requirements specified under Chapter X (Articles 268-278) of the FSCMA and wish to be regulated as such, are required to register with the FSS PEF team within two weeks of their incorporation. ${ }^{34}$

Initially, each registration application was subject to the review and approval by the FSS PEF team. Under this initial regime, the FSS PEF team had thirty days upon receipt of any private equity fund's application to register to make a decision and notify the applicant of the result and reasons therefor in writing. There were three grounds on which the FSS PEF team could reject a private equity fund's registration application: (1) if the applicant failed to meet the technical requirements for registration; (2) if the

29. In US securities regulations, the term 'sophisticated investor' is used to refer to investors who have the capacity to appreciate the complexities and risks of investing in the capital markets or possess the opportunity and resources to bargain for protections when entering into these investments.

30. FSCMA, art 269 (Partners and Contributions).

3I. FSCMA, art 269(I) (Partners and Contributions). Each investor in any collective investment scheme holding I0\% or more of the equity interests of the private equity fund shall be counted for purposes of Article 269: FSCMA, art 269(2) (Partners and Contributions).

32. There is an exception for marketable securities, but this exception may only be invoked with the consent of all other partners. FSCMA, art 269 (Partners and Contributions).

33. FSCMA, art 268(I) (Incorporation and Registration).

34. FSCMA, art 268(3) (Incorporation and Registration). 
registration application contained false information; and (3) if the applicant failed to comply with the FSS' requests for corrections. ${ }^{35}$ This process was later amended in 2015 to become a registration-only regime. ${ }^{36}$

In addition to regulating entry, the FSS PEF team has the authority to terminate private equity funds. The FSS has the power to revoke the registration of the executive partner ${ }^{37}$ of a private equity fund if the executive partner's actions fall under a range of specified circumstances, including cases where it is deemed likely that investors' interests will be seriously undermined. ${ }^{38}$ With respect to the fund itself, the FSCMA sets forth the conditions under which the FSS may revoke the private equity fund's registration, which include registrations made falsely or in an otherwise fraudulent manner, if the fund is dissolved, where there is a possibility that investors' interests will be seriously undermined, or if it is deemed that it would be difficult for the fund to continue its existence. ${ }^{39}$

There are a variety of enforcement mechanisms that are available to the FSS if it decides to proceed against any partner or fund that falls under the circumstances described in the preceding paragraph. With respect to a fund, the FSS PEF team has the power to issue a suspension, or order the transfer of contracts, correction or discontinuation of violations, or to provide public notice or disclosure of the violation. ${ }^{\circ}$ With respect to a partner, the FSS PEF team may demand a dismissal, a suspension of the partners' duties, require salary reductions, issue reprimands, or issue a series of warnings and cautions. ${ }^{4 \mathrm{I}}$

\section{B. First Six Months}

Once partners have paid in their contributions, the fund has six months to invest 50 per cent or more of the contributed amounts in accordance with Article 270 of the FSCMA. ${ }^{42}$ Article 270 specifies not only the types and levels of investments that are required to be made but also requires funds to make certain investments by a certain time. Funds may seek an exemption in cases where the private equity fund can demonstrate unusual difficulty in selecting an investable enterprise, but even in this case they must obtain prior approval of such exception from the FSS PEF team or satisfy a specified carve out. ${ }^{43}$

35. FSCMA, art 268(8) (Incorporation and Registration).

36. These and other private equity regulatory reforms were introduced on 24 July 2015 and went into force on 25 October 2015 .

37. The standard private equity structure is created by an investment manager or sponsor (sometimes referred to as an 'executive partner' in Korean private equity regulation) who solicits investors in the private equity fund to make investments in a portfolio of companies.

38. FSCMA, art 278 (Dispositions against Private Equity Funds).

39. ibid.

40. ibid.

4I. ibid.

42. FSCMA, art 270 (Methods of Management of Property of Private Equity Fund).

43. ibid. One example of a carve out is the 2009 amendment of FSCMA which relaxed certain restrictions on private equity activity, but only for funds specifically targeting small size companies and capital structure improvements: FSCMA, art 278-3 (Special Cases concerning Private Equity Funds for Corporate Financial Stability). 
While private equity funds have some flexibility in managing remaining surplus funds, the law requires that any such management must have no possibility of undermining the soundness in the asset management of the private equity fund. ${ }^{44}$ Even with respect to any remainder, the private equity fund is restricted to investing in property that is specified in the FSCMA, which includes exchange-traded derivatives or specified securities issued by a company specializing in investment and financing for social infrastructure, and other investments as may be prescribed further by Presidential Decree. ${ }^{45}$ Other permitted uses of the surplus include short-term loans, deposits in financial institutions, or investment in securities not exceeding 5 per cent of the property of the private equity fund, in each case, as prescribed by Presidential Decree. ${ }^{46}$

\section{Rest of Term}

Activity restrictions continue to apply to Korean private equity funds beyond formation and the first six months. First, if the private equity fund fails to obtain Io per cent or de facto control within six months after it initially acquires the equity securities of another company, it shall transfer all equity securities to another person, and shall report the transfer to the FSS PEF team without delay. ${ }^{47}$ However, the private equity fund may dispose of such securities within the six month window post-acquisition if it is clearly foreseen that the partners' interests will likely be undermined by holding the equity securities continuously. ${ }^{48}$ Second, at least 50 per cent of the private equity fund must be used for this type of investment activity within the first two years of the fund's formation. ${ }^{49}$ This provision is one example of how Korean regulators took the opportunity to launch a new private equity regulatory regime to create a system that values long-term ownership by private equity.

The FSCMA also imposes strict disclosures and fiduciary duties upon private equity funds, which are two of the most aggressive features of the Korean approach to regulating private equity. Article 272 of the FSCMA imposes a duty of good faith on each executive partner and specifically prohibits the executive partner from trading with the private equity fund, or furnishing the details of assets owned by the private equity fund to any person other than the partners for the benefit of some of the partners or a third party, in each case without the consent of all partners. ${ }^{50}$ To verify compliance, each private equity fund must establish and report its working rules of conduct to the FSS PEF team. ${ }^{5 \text { I }}$ Upon review of such rules, the FSS PEF team has the power to order an amendment or correction to the provisions of the working rules of

\footnotetext{
44. ibid. Some of these restrictions were further relaxed in 2015 as described later in this Section.

45. FSCMA, art 270 (Methods of Management of Property of Private Equity Fund).

46. ibid.

47. FSCMA, art 270(6) (Methods of Management of Property of Private Equity Fund).

48. ibid.

49. ibid.

50. FSCMA, art 272 (Executive Partners, etc.).

5I. ibid.
} 
conduct if the FSS PEF team determines a possibility that partners' interests may be undermined. ${ }^{2}$

Also, general partners are required to deliver periodic reports regarding private equity operation and assets to limited partners. ${ }^{53}$ Such reports are to be accompanied by an explanation of the status of management and property, and the frequency of such reports is to be prescribed by Presidential Decree. ${ }^{54}$ Further, limited partners are given the ability to review the books and records of the private equity fund as well as any special purpose company in which the private equity fund invests. ${ }^{55}$ Such right to inspect can go beyond the books and records of the company and reach the business affairs of the private equity fund if an executive partner has been incompetent or has violated his or her duties as an executive partner. ${ }^{56}$

\section{Summary}

Korean private equity regulation can be seen as an attempt to legally engineer a regulatory ideal of private equity. Korean regulators took this opportunity to introduce a new private equity regulatory regime that not only emulated the successes, but also corrected the malpractices of the then-existing private equity firms. In addition to looking to the successes, avoiding or mitigating the reported shortcomings of foreign private equity firms was another regulatory priority of the Korean regulators. Such shortcomings included moral hazard, short termism, and investor abuse. In particular, curbing the moral hazard of the general partners of private equity firms was a special area of concern for Korean policymakers. ${ }^{57}$

The main concern was that general partners of private equity funds would use the confidential information acquired in connection with the operation of the private equity fund for their private benefit. This explains why the Korean regulatory regime uses law to mandate the provision of periodic reports regarding private equity operations and assets to limited partners and provides limited partners with the right to review the books and records of the private equity fund.

Notably, there is a statutorily imposed and non-waivable duty of good faith and requirement of unanimous consent for related party transactions. ${ }^{58}$ Furthermore, regulators require private equity managers to maintain and submit to them separate working rules of conduct providing for the same. In the US, such matters are decided not by law but through private ordering (ie, as specified in the organizational documents). 59

\footnotetext{
52. ibid.

53. ibid.

54. ibid.

55. ibid.

56. ibid.

57. Park (n 22) 5 I (noting that setting rules to curb general partners' moral hazard was a special area of concern for policymakers).

58. FSCMA, art 272 (Executive Partners, etc.).

59. FSCMA, art 272(7) (Executive Partners, etc.)
} 
Korea has arguably taken a more aggressive approach to regulating private equity than any other country in the world. Notably, the regulations require funds and managers to disclose their assets, liabilities, and transactions to the regulatory authority. US private equity funds also provide such information to certain investors, but not by regulatory mandate. In these ways, the Korean private equity regulatory scheme has mandated by law the types of disclosures, protections, and terms negotiated by the most powerful limited partners in the US and other private equity markets. As a result, investors in Korean private equity funds enjoy protections that would have been only available to a subset of investors in the absence of regulation.

However, taking best practices and making them the baseline is not a costless endeavour, and many have criticized Korean private equity regulation for departing from regulatory norms. Several commentators have criticized the Korean regulatory approach as heavy handed and imposing distortive barriers to entry. ${ }^{60}$ They have suggested moving to the US' mode of regulating private equity funds which they characterize as one where market metrics such as size, reputation, fees charged, and past performance regulate entry and exit from market. In the following Section III, I evaluate whether US private equity regulation is the appropriate comparative frame for Korean private equity regulation.

\section{SELECTING THE PROPER COMPARATIVE FRAME}

In 2006, a Bank of Korea report criticized the Korean regulation of private equity funds and suggested moving closer to the US mode of regulation. ${ }^{6 \mathrm{I}}$ More recently, the National Assembly Research Service in its April 20I4 publication expressed concern that Korea's tougher regulations could prevent the Korean private equity markets from reaching their fullest potential. ${ }^{62}$ Later that year, the Korea Capital Market Institute (KCMI) set out an agenda for reform. ${ }^{63}$ The KCMI Report pushes for lighter regulation of private equity funds to be more consistent with the regulatory stance in other jurisdictions. ${ }^{64}$ Concerned about excessive barriers to entry and onerous registration standards, the KCMI Report suggests a shift from current safety- and soundness-based regulation to more systemic risk focused regulation. ${ }^{65}$

Here, I query whether US private equity regulation is the proper benchmark for Korean private equity regulation. I introduce here the concept of phase-based

\footnotetext{
6o. Kang (n 5) 22-24.

6I. ibid 25 .

62. Ki Hong Kim and Jong Hyun Won, 'Sa-mo-peon-deu hwal-seong-hwa dae-chaeg-ui ju-yo nae-yong-gwa si-sa-jeom [The Key Provisions and Implications of Regulatory Policies to Foster Private Equity]' (National Assembly Research Service I8 April 20I4) <www.nars.go.kr/fileDownload2.do?doc_id= $155978 \&$ fileName $=($ 이슈와 $\% 20$ 논점 831 호-20140418)사모펀드 $\% 20$ 활성화 $\% 20$ 대책의 $\% 20$ 주요\% 20 내용과\%20시사점.pdf> accessed I February 2018.

63. Bo Sung Shin, 'Geul-lo-beol geum-yung-gyu-je heu-leum-gwa u-li-na-la geum-yung-gyu-je-gae-hyeog-ui ba-lam-jig-han bang-hyang [Global Financial Regulatory Trends and the Future Direction of Korean Financial Regulation]' (Korea Capital Market Institute 20I4) <www.kcmi.re.kr/common/downloadm. asp? fid $=\mathrm{I} 7568 \& \mathrm{fgu}=00200 \mathrm{I} \& \mathrm{fty}=004003>$ accessed I February $20 \mathrm{I} 8$.

64. ibid 5 .

65. ibid 4 .
} 
regulation to suggest that the better comparative frame for Korean private equity regulation is the US BDC regime. These two regulatory regimes share the same regulatory goal of introducing a new financial product into the financial markets. When looking through these frames, there are more overlaps between the Korean and US approaches than suggested by the former's critics.

\section{A. The Financial Innovation Spiral and Phase-Based Regulation}

Korea's law-first approach may be unique for private equity but is not new for financial regulation, particularly when the goal is to introduce new products into the market. In other words, the appropriate regulatory strategy that is chosen may sometimes be determined by the phase of the regulation, rather than the investment strategy of the regulated product. To make this point I refer to the life cycle of financial products.

Scholars studying financial innovations refer to this phenomenon as the 'financialinnovation spiral'. They have used the term to describe the process by which financial products initially offered by established intermediaries migrate to the broader markets once they have been seasoned, by way of going through the information provision and standardization benefits provided by established intermediaries. ${ }^{66}$ This spiraling effect has been observed across diverse areas of the financial markets, notably and recently in the derivatives markets. ${ }^{67}$ Derivatives were initially traded on an organized and established exchange (where contracts tend to be public, standardized, transparent, and regulated) and then eventually over-the-counter (where contracts tend to be private, customized, opaque, with low levels of regulatory oversight). ${ }^{68}$

The concept of phase-based regulation rests on the simple claim that the same financial instrument may be subject to radically different regulatory regimes based on where the instrument is situated on the financial innovation spiral. Evaluated through this lens, the proper reference for Korean private equity regulation, whose goal was to introduce private equity into the market, ought to be the experience of other regulations whose goal is to introduce new products into the market.

\section{B. Comparisons with the US First Phase Financial Regulation}

Phase-based regulation suggests that comparing the first chapter of Korean private equity regulation with the last chapter of US private equity regulation is thus not the correct comparative frame in light of their divergent regulatory goals. In the Korean case, the goal of private equity regulation is to cultivate a new private equity market,

\footnotetext{
66. Robert C Merton, 'Operation and Regulation in Financial Intermediation: A Functional Perspective' in Peter Englund (ed), Operation and Regulation of Financial Markets (Stockholm, Ekonomiska Rådet I993) 17.

67. Financial Crisis Inquiry Commission (FCIC), The Financial Crisis Inquiry Report: Final Report of the National Commission on the Causes of the Financial and Economic Crisis in the United States (US Government Printing Office 20I I) 38-5 I.

68. Bruce G Carruthers, 'Diverging Derivatives: Law, Governance and Modern Financial Markets' (2OI3) 4I Journal of Comparative Economics 386.
} 
whereas the goal of private equity regulation in the US is to limit the systemic impact of an already burgeoning product.

Instead, we should compare Korean private equity regulation with other examples where the regulatory aim is to foster growth in the market. The claim I make here is that the phase of the product should be the major determinant of the regulatory strategy taken, particularly at the first phase. The most compelling comparison for Korea may then be the US regulation of BDCs. The BDC is a new strand of private equity firm that was created by law when the US Congress built a channel for public investors to make private investments in small to medium sized companies. I note the striking similarities between the BDC and Korea private equity regulatory regimes in terms of their origins, motivations, and scope to make the claim that when we look to first phase regulation of private equity in the two jurisdictions, the US and Korean approaches to regulating private equity are not as far apart as has been characterized by critics.

BDCs developed as a supplementary regime to the Investment Company Act of I940 (the ICA) which regulates companies that engage primarily in investing, and requires these companies to register with and be regulated as an investment company by the US Securities and Exchange Commission (SEC) unless they fall under an exemption. The Investment Advisers Act of 1940 regulates the sponsors and advisers of investment funds and requires them to register with and be regulated as an investment adviser by the SEC unless they fall under an exemption.

This complex array of regulation has made it costly to operate as a private equity fund unless it can avail itself of some exemption, and many decisions about private equity structures are driven by the exemptions. Another exemption is the option to be regulated as a BDC. The US Congress enacted the Small Business Investment Incentive Act (SBIIA) in I980 to establish a new investment vehicle called a BDC. ${ }^{69}$

The US BDC regulation is similar to the Korea private equity regulatory regime in terms of its origins, motivations, and scope. The intended purpose of the SBIIA was to create a new type of investment vehicle that could promote the flow of capital to small, developing, and financially troubled companies that may otherwise not have access to conventional sources and the public capital markets. ${ }^{70}$ In turn, companies that satisfy the definition of a BDC are exempt from many of the regulatory constraints of the ICA. To enjoy these exemptions, a BDC must comply with the disclosure and activity restrictions specified in the ICA. If we assess and compare these two regulatory regimes, both of which share the regulatory objective of introducing a new investment vehicle into the market, the regulatory principles that are employed by the US and Korean regulators are not that far apart.

However, the main objection to Korean private equity regulation is not the fact of its distance from the US approach to regulating private equity but the effect that such distance may potentially have. In particular, critics have warned that the divergent regulatory approaches could chill investments, discourage innovation, and stall

69. United States Senate Committee on Banking, Housing, and Urban Affairs, Senate Report No 96-958 accompanying Senate Bill 2990 (I980).

70. Small Business Investment Incentive Act of I980, Public Law 96-477, 94 Statutes at Large 2275 (2I October 1980). 
long-term growth in Korea's private equity markets. Another point of resistance has been that requiring disclosures of assets and investors goes against private equity's private nature. There is also the view that private equity firms will always find ways to engage in regulatory arbitrage, and this inevitable exploitation of regulatory loopholes would render the laws moot. Whether these concerns materialized in the Korean private equity markets is evaluated in Section IV.

\section{ASSESSING THE CHILLING EFFECTS OF THE LAW-FIRST APPROACH}

How can a product be regulated without extinguishing the product and at the same time without allowing an escape hatch? These debates are familiar by now. Professor Roberta Romano has pointed to this persistent tendency of private actors engaging in regulatory arbitrage as the biggest takeaway from comparative corporate legal scholarship. ${ }^{7 \mathrm{I}}$ In this Section, I look at the empirical data to evaluate and defuse concerns that the law-first approach taken by Korean regulators has chilled the private equity market.

What I find from this review is that Korean private equity has been successful when measured against its initial goals. As stated at the outset, the impetus for regulation was to foster a Korean-label private equity sector that would be beneficial to the domestic economy, primarily as a counterweight to the growing presence of foreign investors in the Korean takeover market. As a share of the corporate financing, domestic takeover markets and gross domestic product of the Korean economy, Korean private equity has succeeded in gaining significant ground since $2005 .{ }^{72}$ In other words, it can be said that concerns about market distortion and the chilling effect of the Korean regulatory approach on private equity markets have been overstated. The remainder of this Section examines Korean private equity's market trajectory across its three phases: early stages, establishment, and maturity.

\section{A. Early Struggles}

The first Korean private equity fund was established in December 2004 by Woori Bank (totaling 2 ro billion KRW in investments), but was prematurely terminated in October 2005 due to the managers' inexperience and inability to set investment targets. ${ }^{73}$ Like the Woori Bank fund, several other first generation Korean private equity funds suffered from the lack of a track record which created distrust between the managers and investors of the private equity funds, and also made it difficult for investors to evaluate and compare different private equity investment opportunities. ${ }^{74}$

This result is unsurprising given the inherent reputation-based nature of private equity. Often, a private equity fund is associated with a small group of individuals and

\footnotetext{
7I. Roberta Romano, 'A Cautionary Note on Drawing Lessons from Comparative Corporate Law' (I993) IO2 Yale Law Journal 202I, 2029, 2037.

72. Robertson (n I2) 593.

73. Kang (n 5).

74. Sohn (n I7) 36.
} 
their past performance. ${ }^{75}$ Inevitably, Korean private equity firms had to suffer initial growing pains as does any other new initiative in the absence of a track record in its initial stages.

Eventually, to overcome these initial limitations and hurdles, Korean private equity funds relied upon the expertise, brand, and resources of financial institutions until they were able to build a standalone track record. ${ }^{76}$ Notably, the investor base of private equity funds in these initial phases was predominantly institutional. Paragraph 7 of Article 269 of the FSCMA specifically authorizes contributions from the Korea Development Bank and the Industrial Bank of Korea to any private equity fund. ${ }^{77}$

This early stage of Korean private equity regulation and markets demonstrates the importance of situating a financial regulatory regime within the various phases of the development of the underlying product. ${ }^{78}$ In particular, the introductory or shaping phases of a financial product involve reputational risks which no one firm may be prepared to bear. As such, a heavier regulatory hand may be more appropriate in this introductory phase of regulation.

\section{B. Establishment}

As the Korean private equity market became more established, the investor base shifted from institutions to individual investors. Only 56.3 per cent of private equity fund investments were sourced from institutional investors in 2010 , which is almost 25 per cent lower compared to 2005 levels (80.4 per cent in 2005$).{ }^{79}$

In the first five years, the number of domestic private equity funds grew from $\mathrm{I} 5$ in 2005 to I 89 by $201 \mathrm{I}$. These funds have collectively invested 64 billion USD in the Korean markets. ${ }^{80}$ In the Korean takeover market, 70 of the 85 private equity investments completed in $20 \mathrm{II}$ were led by domestic private equity funds, totaling more than 22 billion USD in deal value. By these measures, Korea was the $6^{\text {th }}$ largest private equity market internationally. ${ }^{8 \mathrm{I}}$

Domestic homegrown private equity funds have emerged as leaders in not only the buyout, but also distressed, markets. ${ }^{82}$ The success of the Doosan Group where the incumbent management was able to maintain control while securing 630 billion KRW of liquidity from Korean private equity firms was widely publicized. ${ }^{83}$ Other well-known examples include the private equity fund formed in $20 \mathrm{II}$ by

\footnotetext{
75. Blackstone's CEO has commented that 'you find it is just twenty, thirty or fifty people worldwide who ultimately drive the industry or sector.': David Rothkopf, Superclass: The Global Power Elite and the World They Are Making (Farrar, Straus and Giroux 2009) 45.

76. FSS (n I9) I4.

77. FSCMA, art 269(7) (Partners and Contributions).

78. John D Finnerty, 'Financial Engineering in Corporate Finance: An Overview' (I988) I7 Financial Management I4.

79. FSS (n I9) I4.

8o. ibid.

8I. Private Equity Growth Capital Council (PEGCC), 'Geographic Dispersion of Private Equity Investment in 20I I' (PEGCC 20I2).

82. Hwang (n I3).

83. Sohn (n I 7 ) 37 .
} 
UAMCO and seven banks that has purchased up to 2.3 billion USD of bad debts, the KDB Turnaround Fund formed in 2009 by the Korea Development Bank (KDB) to facilitate government-led restructurings, and the state-run Korea Asset Management Corporation which is also in the business of buying up distressed loans. ${ }^{84}$

\section{Signs of a Mature Market}

Beyond continuous growth in numbers and dollars of funds under management, one notable trend in the Korean private equity markets is the active participation of repeat players. The rate of sponsors with prior private equity fund formation and operational experience in establishing new funds has steadily increased from $5 \mathrm{I} .4$ per cent in 2009 to 9I.I per cent in 20I3. ${ }^{85}$ The Financial Supervisory Service explains that this trend is driven by institutional funds that make their investment decisions based predominantly on the expertise of the executive partner of the private equity fund. ${ }^{86}$ Mandated disclosures about private equity funds' performance and investors can be credited for facilitating this decision-making process.

In addition, the growth of blind pool (as opposed to deal-based) private equity suggest that the level of trust between the managers and investors of private equity funds has significantly improved. With more trust comes more discretion, each of which have been bolstered by the strong information covenants and fiduciary obligations imposed by law. In these ways, two features of the law-first approachincreased transparency and heightened investor protections-have helped to foster, rather than to chill, the Korean private equity market.

Also, in other important ways, the Korean private equity market has exceeded initial regulatory goals. Korean private equity firms have gained a foothold on the global private equity stage. Notably, Korean private equity firms have been actively investing in not only domestic but also foreign firms. In 2010, roughly 9.5 per cent of the 263 targets of Korean private equity funds were foreign firms. ${ }^{87}$ In 2015 , approximately Io per cent of the I 40 targets were foreign firms. ${ }^{88}$ This trend was buoyed by the National Pension Service' (NPS) Corporate Partnership program under which NPS contributes to a private equity fund which then jointly invests alongside a Korean corporation in overseas investments.

84. Seonjin Cha 'Uamco Plans IPO as Korean Buyer of Bad Loans Sees Market Growth' Bloomberg (New York, 2 Jun 20II).

85. FSS, 'Gug-nae sa-mo-tu-ja-jeon-mun-hoe-sa do-ib Ionyeon-gan-ui byeon-hwa mich pyeong-ga [Io Year Review of Domestic Private Equity Funds]' (FSS Io March 2015) $2<$ www.fss.or.kr/fss.hpdownload?file=

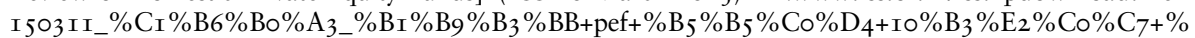

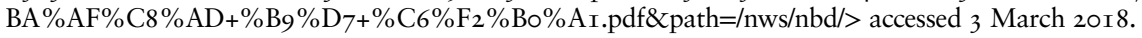

86. FSS (n 19) 2, 5 .

87. FSS, 'Sa-mo-tu-ja-jeon-mun-hoe-sa Sil-mu-an-nae [PEF Handbook]' (FSS December 20 I I) 20.

88. FSS, 'I 5 -Nyoun, PEF dong-hyang mit si-sa-jeom [2015 PEF Trends and Implications]' (25 April 20I6)

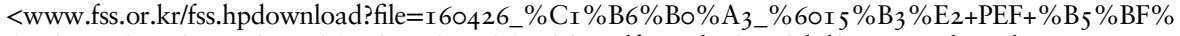

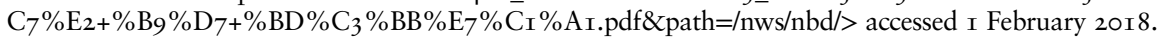


Korean private equity has developed its own innovations, ${ }^{89}$ introducing a new program where individual investors with 5 million KRW can invest in private equity funds. On 29 May 20I6, the FSC announced that it is working to revise regulations to permit a publicly-offered fund which invests in private equity funds. Such add-ons have been facilitated by clearly articulating the regulatory ideal for private equity, which is another feature of the law-first approach to regulation.

\section{REGULATORY DIVERGENCE AND MARKET COHERENCE}

The chronological survey of the early, establishment, and maturity phases of the Korean private equity market provided in Section IV shows that Korean private equity has grown to impressive levels under the law-first approach. The discussion of Korean private equity regulation in Section II demonstrates that the Korean approach is situated at the opposite end of the regulatory spectrum compared to the approach taken by other jurisdictions. And yet, the discussion of the Korean private equity market in Section IV demonstrates that the manner in which Korean private equity conducts its business bears striking similarities to foreign private equity funds..$^{90}$ One way to understand the ability of divergent regulatory schemes to achieve market coherence is by acknowledging that the same financial instrument may require a different regulatory strategy according to where it is situated within its life cycle, as discussed in Section III. In the final Section of this article, I highlight the important role of financial and regulatory agents in achieving such alignment between Korean and foreign private equity markets.

Since the time of Alan Watson's influential work on legal transplants to explain the diffusion of legal models in the colonial period, ${ }^{9 \mathrm{I}}$ new theories about diffusion in the post-colonial period have emerged. But even normative arguments in favour of diffusion must be properly supported by first choosing the correct benchmark and then designing the proper channels to achieve the desired regulatory results. Here, I rely primarily on the works of Justin Robertson and Holger Spamann on financial returnees and contemporary legal transplants, respectively, to explain how Korea uses law-first regulation to mobilize state and market actors to achieve its articulated ideal of private equity. What is notable is the role of these actors in blending civil and common law elements to obtain this outcome.

\section{A. Financial Returnees}

Justin Robertson credits 'financial returnees' as the key transmission channel and intermediary for financial processes originating from Anglo-American markets into

89. Mi Young Yang, 'Sa-mo-peon-deu, 5ooman-won-i-myeon tu-ja-han-da [Investors with 5 Million KRW Can Now Invest in PEF]' Bizwatch (Seoul, 29 May 20I6) <www.bizwatch.co.kr/pages/view.php?uid= 23369> accessed I February 2018.

90. Robertson (n I2) 597 ('While Korean private equity manifests differences to the US model - with far fewer layoffs for example - the similarities in areas such as conducting majority control investments, installing new managers at increased pay levels, drawing on high levels of debt, foreign fundraising, lower capital gains taxation and the use of international tax havens are striking.').

9I. Alan Watson, Legal Transplants: An Approach to Comparative Law (2nd edn, University of Georgia Press 1993). 
East Asian finance. ${ }^{92}$ Financial returnees refer to elites returning to domestic finance after spending significant time in global finance. ${ }^{93}$ In particular, financial returnees are responsible for bringing about changes that are consistent with the Anglo-American model of capitalism. ${ }^{94}$ While small in number, they exert disproportionate impact on the economic direction of markets. Three out of four of the partners and directors of MBK Partners, the largest Korean private equity firm, have received an American education and have worked for a US investment bank or PE fund. ${ }^{95}$

According to Robertson, the financial returnees' greatest strengths are their ability to introduce the American way of doing private equity (their sponsoring country) in a manner that is sensitive to local and cultural sensitivities of Korea (their home country). Robertson's ideas goes against the work of other scholars ${ }^{96}$ that point to interests of local elites as contrary to global business. ${ }^{97}$ However, it must be acknowledged that this resistance to foreign influence was what fueled the growth of the Korean private equity market. ${ }^{98}$ One way to reconcile these competing views is to interpret the lawfirst approach of regulators as setting regulatory upper bounds on the agents' behaviour.

The heavy hand of Korean private equity regulation has, paradoxically, made way for more innovation in the Korean private equity market. For example, unlike US private equity firms that are known to widely publicize their profits, Korean private equity has been much more low-profile, mindful of the risk of offending regulators or the public. ${ }^{99}$ This has contributed to the receptive posture of the Korean government and public to this new strain of private equity, and this consensus has in turn facilitated a market that is in line with foreign trends while remaining compliant with cultural and regulatory norms.

Another concern may be that financial returnees are so effective as to erode the initial bounds set by the Korean private equity regulatory mandate. Many have pointed to how financial market liberalization measures that were credited with achieving Korea's remarkable economic growth were later blamed for some of the Korean financial market's vulnerabilities during the Asian Financial Crisis. ${ }^{100}$ Yet another function of the law-first approach is that it sets the lower bounds on agents' behaviour,

\footnotetext{
92. Robertson (n I 2) 579.

93. ibid.

94. Roberton (n I2) 580.

95. Roberton ( $\mathrm{n}$ I2) 587.

96. Ronald J Gilson, Henry Hansmann, and Mariana Pargendler, 'Regulatory Dualism as a Development Strategy: Corporate Reform in Brazil, the United States, and the European Union' (201 I) 63 Stanford Law Review 475, 478 (citing Mancur Olson, The Rise and Decline of Nations (Yale University Press I982), who notes the 'resistance of the established economic and political elite to growth-promoting reforms').

97. Leslie Sklair, The Transnational Capitalist Class (Wiley-Blackwell 2000) I2.

98. Robertson (n I2) 58 I.

99. Robertson (n I2) 595 .

Iо०. See eg Kurtulus Gemici, 'Social Origins of Financial Crises' in Kallidaikurichi E Seetharam (ed), A Tale of Two Crises: A Multidisciplinary Analysis (Routledge 2013) 37 (explaining the causes of the Asian Financial Crisis); Jong-Wha Lee, Young Soo Lee, and Byung-Sun Lee, 'The Determination of Corporate Debt in Korea,' (2000) I4 Asian Economic Journal 333, 334 (describing the fragility of highly leveraged Korean firms and their lenders that were exposed by the Asian Financial Crisis).
} 
which provides legitimacy and prevents a race to bottom by converting best practices into legally-mandated baselines.

In addition, Robertson's account aims to supplement the existing accounts of the Korean economy which he views as too narrowly focused on examining only the role of the state. ${ }^{\text {IOI }}$ Here, I take an intermediate view to explain that the state, through its lawfirst approach, has both facilitated and shaped the participation of financial returnees.

\section{B. Regulatory Returnees}

A separate project of Holger Spamann traces formal diffusion using evidence of visible foreign influence (measured by citations, involvement of foreign trained lawyers, and evidence of copying of statutes). ${ }^{\text {IO2 }}$ He examines the specific channels of diffusion, such as legal development and cooperation agencies, trade and investment flows, and student migration, which he refers to as substantive diffusion. This distinction between formal and substantive diffusion helps shed light on tricky cases where one country follows a foreign model without explicit acknowledgement of the foreign influence, versus one country that has a totally autonomously developed project that uses a foreign model for technical simplicity or even as a decoy. ${ }^{\text {IO3 }}$

The Korean case is consistent with Spamann's account that it is not some inherent features of 'civil law' versus 'common law' traditions but rather the diffusion channel that explains convergence. The explanation that Professor Spamann offers is that when there is an opportunity to change the law, one of the sources that the country looks to for guidance is the other members of its legal family. As networks expand, the usual boundaries between common and civil law jurisdictions become less meaningful. As individual agents cross over between the lines separating common law and civil law jurisdictions, blended families become more common.

The Korean private equity example is a prime example of such blending. In the Korean case, because there was no regulatory precedent to rely on, Korean lawmakers and regulators looked to the markets to determine the appropriate scope and method of regulation. Drafting a special set of rules to apply to private equity when no such framework existed elsewhere created both challenges and opportunities for Korean regulators. The clean slate allowed lawmakers to set a regulatory ideal and to design laws and tailor their application to achieve that ideal. In doing so, Korean regulators took cues from the then-leading foreign private equity firms in the US and the UK to set the bounds of private equity regulation. This emulation was done without regard to whether such benchmark jurisdictions were associated with common law or civil law traditions. At the same time, the regulatory strategy taken was consistent with Korea's civil law tradition, which can be described as a strict, uniform, and rule-based framework. In this way, Korea's law-first approach to foster domestic private equity

\footnotetext{
гог. Linda Weiss, 'Guiding Globalisation in East Asia: New Roles for Old Developmental States' in Linda Weiss (ed), States in the Global Economy (CUP 2003) 245.

I02. Holger Spamann, 'Contemporary Legal Transplants: Legal Families and the Diffusion of (Corporate) Law’ (2009) Brigham Young University Law Review I8 I3.

IO3. ibid I 852 .
} 
markets is an apt example of the blending of civil law traditions with financial innovations that are traceable to common law jurisdictions. ${ }^{\text {IO4 }}$

\section{CONCLUSION}

The Korean private equity regulatory strategy is one that I term a 'law-first' approach. In other words, it is the law, rather than markets, that sets the metes and bounds of private equity funds in Korea. The main objection to Korea's law-first approach has been that heavy-handed regulation could chill investment, discourage innovation, and stall long-term growth. A review of the Korean private equity market, however, shows that many of these concerns did not in fact materialize in the ways or with the intensity that the critics had feared. Domestic homegrown private equity funds emerged as leaders in the takeover market, and the amount of capital raised and invested has continued to grow year after year.

Yet in 2015 , the Korean FSS reformed private equity regulation to conform to global standards. ${ }^{105}$ This article suggests that reforming the Korean regulatory approach to conform to global standards without an assessment of the proper comparative frame and without considering the stage of development of the product being regulated may undo the important milestones achieved by the Korean private equity regulatory experiment. The Korean regulators took the lessons learned from the Asian Financial Crisis as an opportunity to design laws to cultivate a domestic private equity market that was not then in existence. The regulatory goals were ambitious and not only sought to remove legal and regulatory barriers to facilitate a private equity industry that was not only aligned with, but also exceeded, then-existing global standards. The creation of a more long-term and stable private equity market was an important goal for private equity regulation, even if it was at the cost of more burdensome regulations.

My assessment of the Korean regulatory experience is that it was successful overall when measured against the initially stated goals of such regulations. The Korean regulatory experiment provides a powerful counterexample to the existing discourse that private equity cannot be effectively regulated, or that any attempt to regulate will be thwarted by private actors' efforts to reorganize themselves and exploit regulatory loopholes. While a large part of Korea's success is likely attributable to the unique legal and regulatory political and market conditions that were present at the time, this regulatory case study shows one way to execute private equity regulations effectively when the conditions are ripe.

I04. J Mark Ramseyer, 'Mixing-and-Matching Across (Legal) Family Lines' (2009) Brigham Young University Law Review I7OI (illustrating the possibility of countries switching and borrowing across legal family lines).

I05. See text accompanying n 35 . 